\title{
Discussion on the Construction of Independent College's Teaching Quality Control System Based on Customer Satisfaction
}

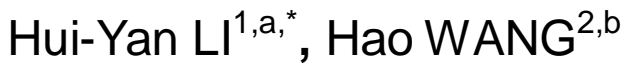 \\ ${ }^{1}$ Management Department, Sanya University, Hainan,P.R.China, 572000 \\ ${ }^{2}$ Sanya Aviation \& Tourism College,School of Tourism \& Hotel Management, Hainan, P.R.China \\ alinda770206@sina.com, bwh771201@126.com \\ ${ }^{*}$ Corresponding author
}

Keywords: Independent college, Teaching quality control system; Educational concept

\begin{abstract}
Independent College is public private secondary college after the standard of ministry of education in 2003. Specifically, it means common colleges and universities above undergraduate course cooperate with the social organizations or individuals outside the state institutions, holding the undergraduate education institutions with non-national financial allocations. This paper expounds the establishment of the concept of the total quality control (TQC) of teaching and the determination of teaching quality standard, and puts forward some important means and measures for constructing the teaching quality system adapted to the development of independent college and for guaranteeing the teaching quality from the perspective of customer satisfaction.
\end{abstract}

\section{Introduction}

In recent years, accompanied by continuous mass students, the quality of education is increasingly prominent, the quality of education has become one of the central issues of higher education reform and development, has become an important indicator of evaluating schools and the main factors affecting the survival and development of the school.IS09000 quality management system proposed new quality concept ---"customer focus, establish customer satisfaction", customer satisfaction became the starting and end point of the quality strategy in 21 st century, but also provided important ideas for promoting the reform of higher education, improve teaching quality of higher education and to achieve customer satisfaction.

Independent colleges generally rely on its parent university, its educational philosophy, professional setting, training programs and even textbooks are mostly derived from the parent university, or to make some changes according to their own circumstances on the basis of the parent university. Due to the lack of features, coupled with the impact of their own resources or lack of teaching, teachers cannot be fully guaranteed, inadequate funding, inadequate teaching facilities and other factors, making the research on education quality and how to build brand awareness and development of independent colleges from the perspective of customer satisfaction become a major issue for all independent colleges face together.

\section{The characteristics of independent college students}

Since independent college pilot in 1999, it has been rapid development and become an important part of higher education. Currently, there are 300 independent colleges in our country. Although the independent college has been rapid development, but due to the special nature of independent college students, the quality of teaching has always been a matter of great concern to the community. Independent college students have their own unique characteristics.

\section{Ambitious, but lack of perseverance and self-confidence}

Overall quality of the independent college students is relatively high; they grew informed, active, broad interests, strengths prominent. Most of them have the ambitious goal. But on the other hand, 
some of them lack the toughness and perseverance. Survey shows that $34 \%$ of independent college students consider themselves "lack of stamina," while college students this data is only $25 \%$. Some students dampened confidence caused by the disorder college entrance examination achievement, often hesitate in the face of difficulties, negative retreat, lack of self-confidence, and show some sense of inferiority.

\section{Strong sense of innovation, but poor sense of self-management and collaboration}

Independent college students accept new things quickly, desire for independence, thinking more active, focusing on updated information, and have a positive attitude for scientific and technological innovation, entrepreneurship and other practices with the courage to put into action. But this sense of innovation does not match the ability of self-regulation of them. The students showed poor awareness of self-management on the one hand, college life require students to have a strong self-management skill, but some students trapped in undisciplined lifestyle, living without timing, learning erratic, uncontrolled spending money, hoping to get someone else to take care of, but rarely think to take care of others. On the other hand, poor teamwork consciousness make them exposed many weaknesses and shortcomings once lived in a group needing for mutual respect, humility, love each others.

\section{Indulgent, but relatively weak sense of collectivism}

Independent college student has ideological active, cheerful, interests, widespread hobby and strong sense of participation. They have courage to express themselves especially in terms of their expertise. But some of the students are also self-centered, lack of collective consciousness, enthusiasm and initiative of participating in group activities is not high, and evenly it is difficult for them to achieve daily management for schools requirements. In particular, there is a considerable part of the student have strong utilitarian.

\section{Approaches to improve quality of teaching comprehensively based on customer satisfaction}

The relationship between schools and the "customer" is the chain, steadily locked. It is necessary to measure the school's point of view and their respective levels of achievement from the "customer" actual demand for higher education with "customer" positive attitude of educational outcomes. To create a truly teaching quality control system from the "client" perspective in aspects of concept, positioning, organization, resources, feedback, etc., forming a virtuous circle mechanism, not only embodies the university "customer-oriented" as a new sense of quality, but also provides a guarantee for independent colleges to improve education quality continuously and achieve sustainable development ultimately.

\section{Establish total quality management philosophy}

Total quality management philosophy is business management theory and methods to ensure product quality, and the implementation of total quality management in teaching activity is applications of corporate management mechanism into the field of education. The quality of teaching involved in all aspects of teaching activities, and therefore the features of quality of teaching management is multi-factor, multi-level and wide range. Although many colleges and universities have done a lot of work in teaching quality management, such as the establishment of teaching supervision system, teaching evaluation, peer evaluation of teaching, teaching leadership assessment, graduation design (thesis) and monitoring examinations, but still lacking the overall quality of teaching monitoring system such as monitoring, feedback and improvements to guarantee improve quality of teaching. Establish total quality management philosophy is all-round monitoring and evaluation of the quality of teaching three basic elements (inputs, processes, outputs) in the whole process of teaching and learning activities, such as teaching facilities monitoring, teaching management level monitoring and faculty monitoring. 


\section{Grasp location and determine the standards of teaching quality}

Training objectives of independent colleges are generally targeted in applied talents, which meet the social division of labor and social-economic development of the personnel requirements. But how to reflect specific knowledge, applied talents ability levels and academic standards in teaching programs, the quality requirements in the training way lack of in-depth investigation and research. The quality of teaching refers to the degree that student changes in the teaching activities, under certain conditions (access to the knowledge, skills and values formation) reaches a given level of personnel training and quality objectives and accepted by public. "The established quality of personnel training objectives" is the quality of teaching standards. It can be seen, the establishment of appropriate teaching quality standards is the fundamental basis for building an independent college teaching quality assurance system. Teaching quality standards is the level which personnel training should reach in all aspects of knowledge, ability, etc., but also the personnel training and quality requirements management measures to achieve the desired objectives. Therefore, the establishment of teaching quality standards should note the following: identify the key factors affecting the quality of teaching; identify the key link in teaching activities; learn advanced quality management theory and methods; determine the basic content of quality standards combined with the actual situation of independent colleges.

\section{Establish viable organization security system}

Organization institution is an organization may exercise its functions and then somehow establish responsibilities, authority and relationship with each other, teaching quality control and assurance functions under the university educational administration department is currently common practice. However, the quality of teaching depends on teachers' teaching and students learning, but also depends on other factors such as teaching facilities, teaching staff, the quality of students, practice teaching and campus culture and so on. The educational administration department is responsibility and limited powers, because the quality of teaching competence involves simultaneously belong to other functional departments. In addition, the functions of teaching decision-making, teaching management, quality control is in a set of educational administration department easily produce teaching quality information feedback systems rely mainly on self-feedback case management, is not conducive to timely decision-making, self-regulation and improvement of the quality of teaching, thus will be restricted effective operation of the guarantee system. We must set a special quality management and monitoring agencies to coordinate the responsibilities, authorities, relationship between various functional agencies and department in quality assurance work.

\section{Strengthen resource management and improving college conditions}

Independent Colleges rely on the support of its parent in the beginning, but hey will lose their own characteristics if copy blindly. Thus independent college can apply the resources which parent university provides to actualize self-development and self-improvement. Applied talents need to have an application-oriented faculty; independent college teachers should pay special attention to follow two aspects: one is the introduction of outstanding teachers with extensive experience in teaching and research capabilities from the mother; the second is the introduction of the first production line staff with extensive practical experience from enterprises. Meanwhile, through the hiring of experts and scholars of the community, independent colleges can establish a stable, high-quality part-time teachers from the community. In addition, teachers should actively encouraged to do some scientific research and social services, sending young teachers to enterprises testing exercise, to enhance the development and application capabilities. Consider the limited financial resources in most of independent colleges, there are two ways to ease the pressure of financial constraints: Firstly, take full use of maternal resources and rationally plan, construct and manage the teaching facilities, Secondly, obtain the support of the main part of the marketbusiness, industrial and their capital by means of market mechanisms. 


\section{Establish teaching quality monitoring and feedback mechanism}

According to ISO9000 quality management standard, the quality assurance must be emphasized that the "process control" and "quality improvement." Emphasis on "process control" emphasizes preventive measures, so that the actual quality of teaching as close to the quality of teaching standards to ensure the quality of teaching; and the "quality improvement" is process to make the teaching quality level reached new heights. Safeguard the quality of teaching, the teaching process must be monitored, while the results of the monitoring feedback. The establishment of teaching quality monitoring and feedback mechanisms including four aspects: First, the choice of teaching quality control points; Second, choose the means for monitoring control points; third, analyze the differences between the actual quality and teaching quality standards and feedback; Fourth, propose the improvement measures according to the feedback.

\section{Summary}

In the new century, the quality of teaching is the cornerstone of the survival and development of universities. Independent college is a reform initiatives innovation institutional mechanisms and management innovation, supporting an exploration of private higher education in the new situation. In order to ensure the healthy development of independent colleges, improve the quality of teaching is only the starting point not the end either now or in the future.

\section{Acknowledgement}

This research was financially supported by Hainan Department of Education (QJI12522).

\section{References}

[1] Goldrick, Liam. Improving Teacher Evaluation to Improve Teaching Quality. http://www.nga.org/cda/files /1201 Improving teacheval.pdf.(2002)1-10.

[2] Lomas laurie, nicholl Gill. Enhancing Teaching Quality through Peer Review of Teaching Quality in Higher Education,(2005)137-149.

[3] Ediger, Marlow. Assessing Teaching Quality in Higher Education.N/A (2000) .

[4] Information on http://www.moe.edu.cn/edoas/website18/info25091.htm. 